\title{
Nocardioides aestuarii sp. nov., isolated from tidal flat sediment
}

\author{
Hana Yi and Jongsik Chun \\ School of Biological Sciences, Seoul National University, 56-1 Shillim-dong, Kwanak-gu, Seoul \\ 151-742, Republic of Korea
}

Correspondence

Jongsik Chun

jchun@snu.ac.kr

\begin{abstract}
A strictly aerobic, non-motile, rod-shaped actinomycete, designated strain $\mathrm{JC}^{2056}{ }^{\top}$, was isolated from a sediment sample of getbol, the tidal flat of Korea. Results of 16S rRNA gene sequence analysis indicated that the isolate belonged to the genus Nocardioides, with the highest similarity being to Nocardioides luteus KCTC $9575^{\top}(95 \cdot 7 \%)$. The major menaquinone was MK-8 $\left(\mathrm{H}_{4}\right)$, and predominant cellular fatty acids were iso-16:0 and iso-16:1 $\mathrm{H}$. The DNA $\mathrm{G}+\mathrm{C}$ content was $70 \mathrm{~mol} \%$. Based on the morphological, physiological, biochemical and chemotaxonomical data presented in this study, strain $\mathrm{JC}^{2} 256^{\top}$ should be classified as a novel species, for which the name Nocardioides aestuarii sp. nov. is proposed; the type strain is JC2056 ${ }^{\top}\left(=\right.$ IMSNU $14029^{\top}=$ KCTC $9921^{\top}=$ JCM $\left.12125^{\top}\right)$.
\end{abstract}

Recently, a novel Nocardioides species was isolated from getbol (Korean tidal flat) of Ganghwa Island in Korea, and described as Nocardioides ganghwensis (Yi \& Chun, 2004). An additional Nocardioides strain, JC2056 ${ }^{\mathrm{T}}$, was also isolated from getbol sediment near the site $\left(37^{\circ} 36^{\prime} 22 \cdot 3^{\prime \prime} \mathrm{N}\right.$, $126^{\circ} 22^{\prime} 59 \cdot 4^{\prime \prime} \mathrm{E}$ ). In this study, the newly isolated strain was the subject of a taxonomic investigation to elucidate the identity; the name Nocardioides aestuarii sp. nov. is proposed for this isolate.

Strain JC2056 ${ }^{\mathrm{T}}$ was isolated using MR2A [R2A (Difco) supplemented with artificial sea salts (Sigma)] and was routinely cultured on marine agar 2216 (MA; Difco) at $30{ }^{\circ} \mathrm{C}$ and maintained as a glycerol suspension $(20 \%, \mathrm{w} / \mathrm{v})$ at $-80^{\circ} \mathrm{C}$.

Primers, PCR condition and sequencing method for the $16 \mathrm{~S}$ rRNA gene were as described previously (Chun \& Goodfellow, 1995). Phylogenetic analyses were performed following the same methods and procedure described previously (Yi \& Chun, 2004) using the jPHYDIT (available at http://chunlab.snu.ac.kr/jphydit) and PAUP 4.0 (Swofford, 1998). Initial BLAST searching against GenBank using the $16 \mathrm{~S}$ rRNA gene sequence of strain JC2056 ${ }^{\mathrm{T}}$ (1380 bp) indicated that the test strain belonged to the genus Nocardioides. The newly determined sequence was then aligned manually against representatives of the family Nocardioidaceae using secondary-structure information of bacterial 16S rRNA. Domains used to construct the phylogenetic trees were the regions available for all sequences

Published online ahead of print on 19 July 2004 as DOI 10.1099/ ijs.0.63192-0.

The GenBank/EMBL/DDBJ accession number for the partial $16 \mathrm{~S}$ rRNA gene sequence of strain $\mathrm{JC} 2056^{\top}$ is AY423719. (positions 38-1431; Escherichia coli numbering system), excluding positions showing ambiguous alignment (positions 76-95, 199-219, 455-478, 1025-1037 and 1135-1140). On the basis of $16 \mathrm{~S}$ rRNA gene sequence similarity, the closest cultured bacterial relatives were Nocardioides species (93.6-95.7\%), Marmoricola aurantiacus DSM $12652^{\mathrm{T}}$ $(93 \cdot 1 \%)$ and Aeromicrobium species $(92 \cdot 7-93 \cdot 0 \%)$. The highest sequence similarity was observed with Nocardioides luteus KCTC $9575^{\mathrm{T}}(95 \cdot 7 \%)$, which is below the recommended cut-off value of $97 \%$ for bacterial species definition (Stackebrandt \& Goebel, 1994). This relationship between our isolate and other members of the family Nocardioidaceae was also evident in the phylogenetic tree (Fig. 1). Although the branching position varied depending on the tree-making algorithm, the phyletic line of strain JC2056 ${ }^{\mathrm{T}}$ was clearly placed within the Nocardioides clade based on all four tree-inferring methods used in this study. Our isolate was recovered as a sister group to the subclade containing Nocardioides albus KCTC $9186^{\mathrm{T}}$ and N. luteus KCTC $9575^{\mathrm{T}}$ in the neighbour-joining and FitchMargoliash trees with low bootstrap values (35-37\%), or formed a clade with Nocardioides plantarum NCIMB $12834^{\mathrm{T}}$ in the maximum-likelihood tree with less than $50 \%$ bootstrap support. The most-parsimonious tree showed that our isolate branched out between $N$. plantarum NCIMB $12834^{\mathrm{T}}$ and the subclade containing $N$. albus KCTC $9186^{\mathrm{T}}$ and $N$. luteus KCTC $9575^{\mathrm{T}}$ with less than $50 \%$ bootstrap support.

All the phenotypical characters were investigated as described previously (Yi \& Chun, 2004). Morphological, physiological and biochemical tests were performed using $\mathrm{MA}$ as the basal medium at $30^{\circ} \mathrm{C}$. The results of biochemical, physiological and morphological tests are given in Table 1 and the species description. 


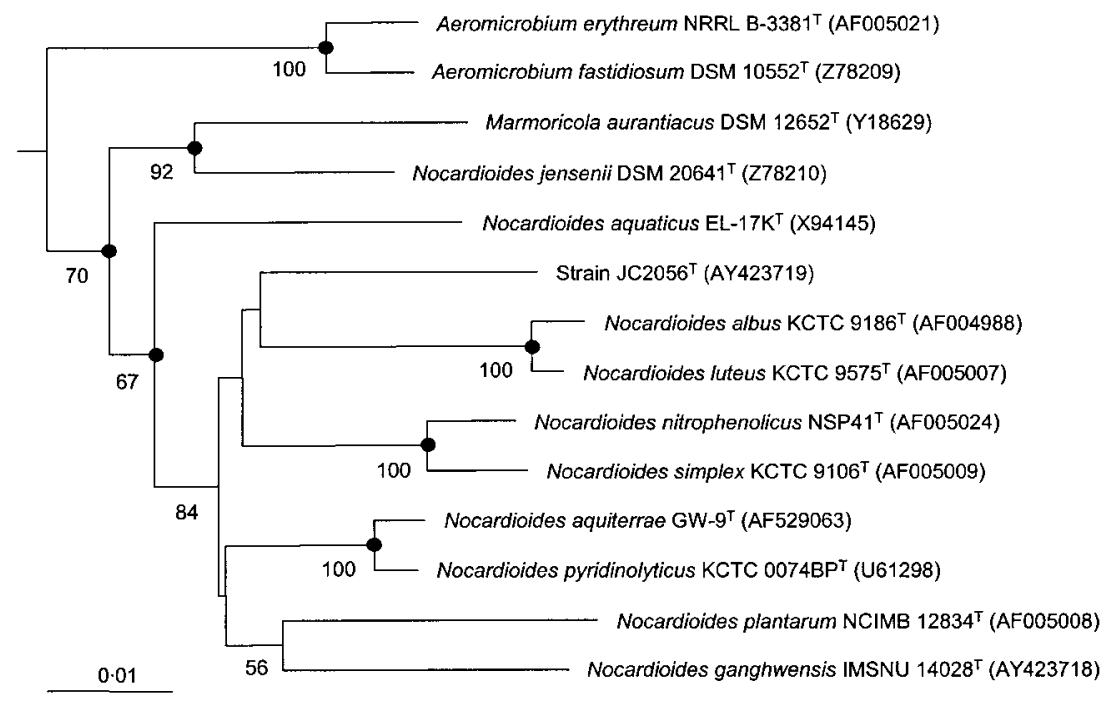

Fig. 1. Neighbour-joining tree based on nearly complete $16 \mathrm{~S}$ rRNA gene sequences showing relationship between strain $\mathrm{JC}^{2056^{\top}}$ and members of the genus Nocardioides. Percentage bootstrap values of $>50 \%$ (1000 resamplings) are given at the nodes, and solid circles indicate that the corresponding nodes (groupings) are also recovered in Fitch-Margoliash, maximum-likelihood and maximum-parsimony trees. Nocardia asteroides ATCC $19247^{\top}$ (GenBank/EMBL/DDBJ accession no. Z36934) was used as the outgroup (not shown). Bar, 0.01 nt substitution per position.

Chemotaxonomical characteristics of strain $\mathrm{JC} 2056^{\mathrm{T}}$ were determined using the cells grown at $30^{\circ} \mathrm{C}$ for 3 days on MA or in $\mathrm{MB}$ (marine broth 2216; Difco). Menaquinone and DNA G $+\mathrm{C}$ content (mol\%) were determined by HPLC as described previously (Yi \& Chun, 2004). Analysis of fatty acid methyl esters was performed by GLC according to the instruction of the Microbial Identification System (MIDI). Cell-wall diamino acid was determined as described by Staneck \& Roberts (1974). Most chemotaxonomical characters of strain JC2056 ${ }^{\mathrm{T}}$ were typical of the genus Nocardioides (Collins et al., 1994; Lawson et al., 2000; O’Donnell et al., 1982; Prauser, 1976, 1986; Suzuki \& Komagata, 1983; Yoon et al., 1997, 1999, 2003); MK-8 $\left(\mathrm{H}_{4}\right)$ as a major menaquinone, LL-DAP as a cell-wall diaminopimelic acid, $70 \mathrm{~mol} \%$ as the DNA $\mathrm{G}+\mathrm{C}$ content. The cellular fatty acid composition of our isolate also resembled that of other Nocardioides species, but was differentiated by high proportions of iso-16:0 (52.0\%) and iso- $16: 1 \mathrm{H}$ $(14 \cdot 5 \%)$.

On the basis of $16 \mathrm{~S}$ rRNA gene phylogeny and chemotaxonomy, it is clear that our isolate belongs to the genus Nocardioides. Low $16 \mathrm{~S}$ rRNA gene sequence similarity values to Nocardioides species $(93 \cdot 6-95 \cdot 7 \%)$ indicate that strain $\mathrm{JC}^{2} 256^{\mathrm{T}}$ represents a novel genomic species in the genus. Moreover, several morphological and physiological characteristics can be weighted to differentiate our isolate from other Nocardioides species (Table 1). Based on the polyphasic evidence presented in this study, it is fair to conclude that strain JC2056 ${ }^{\mathrm{T}}$ merits novel species status in the genus Nocardioides. The name Nocardioides aestuarii sp. nov. is proposed for strain JC2056 $6^{\mathrm{T}}$.

\section{Description of Nocardioides aestuarii sp. nov.}

Nocardioides aestuarii (aes.tu'ar.i.i. N.L. gen. n. aestuarii of the tidal flat).
Gram-positive and strictly aerobic bacterium. Oxidasenegative, catalase-positive and not acid-fast. Spores are not formed. Cells are non-motile rods of approximately $0 \cdot 9-2 \cdot 1 \times 0 \cdot 3-0 \cdot 4 \mu \mathrm{m}$. Colonies on MA are ivory, circular, convex, glistening, opaque and butyraceous and have an entire margin. Colonies are approximately $0.5-1 \mathrm{~mm}$ in diameter after 3 days on $\mathrm{MA}$ at $30{ }^{\circ} \mathrm{C}$; they reach the maximum diameter of $1-2 \mathrm{~mm}$ after 5 days. Substrate or aerial mycelium is not observed. Grows at $20-35^{\circ} \mathrm{C}$, $\mathrm{pH}$ 6-10 and $0-8 \%(\mathrm{w} / \mathrm{v}) \mathrm{NaCl}$; optimal growth at $30^{\circ} \mathrm{C}$, $\mathrm{pH} 7$ and $0-2 \%(\mathrm{w} / \mathrm{v}) \mathrm{NaCl}$. Major menaquinone is MK-8 $\left(\mathrm{H}_{4}\right)$. Cell-wall diamino acid is LL-DAP. Major fatty acids are iso- $16: 0(52 \cdot 0 \%)$ and iso- $16: 1 \mathrm{H}(14 \cdot 5 \%)$. In addition, $17: 1 \omega 8 c(7 \cdot 0 \%), 10 \mathrm{Me}-17: 0(3 \cdot 1 \%), 18: 1 \omega 9 c$ $(2 \cdot 7 \%)$, iso-14:0 (1.8\%), anteiso-17:0 (1.8\%), $10: 0$ $(1 \cdot 4 \%), 10 \mathrm{Me}-16: 0(1 \cdot 3 \%)$, anteiso-15:0 (1.3\%), iso$15: 0(1 \cdot 2 \%)$ and a mixture of iso- $15: 02-\mathrm{OH}$ and $16: 1 \omega 7 c$ $(1.3 \%$; MIDI system cannot differentiate these two fatty acids) are present. Trace amount of tuberculostearic acid $(0 \cdot 3 \%)$ also exists. DNA G + C content is $70 \mathrm{~mol} \%$. Results of API 20NE, API ZYM kits, decomposition of highmolecular-weight substrates and carbon source utilization are given in Table 1.

The type strain is $\mathrm{JC}^{2056^{\mathrm{T}}}\left(\mathrm{IMSNU} 14029^{\mathrm{T}}=\mathrm{KCTC}\right.$ $\left.9921^{\mathrm{T}}=\mathrm{JCM} 12125^{\mathrm{T}}\right)$. Isolated from sediment of getbol (tidal flat) in Ganghwa Island, Korea $\left(37^{\circ} 36^{\prime} 22 \cdot 3^{\prime \prime} \mathrm{N}\right.$, $\left.126^{\circ} 22^{\prime} 59 \cdot 4^{\prime \prime} \mathrm{E}\right)$.

\section{Acknowledgements}

This work was supported by the 21C Frontier Microbial Genomics and Applications Center Program (grant MG02-0101-001-2-1-0), the Strategic National R\&D Program through the Genetic Resources and Information Network (grant M1-0219-00-0018) and the BK21 Research Fellowship (the Ministry of Education and Human Resources Development), Republic of Korea. 


\section{Table 1. Characteristics that differentiate strain $\mathrm{JC} 2056^{\top}$ from other Nocardioides strains}

Strains: 1, Strain JC2056 ${ }^{\mathrm{T}}$; 2, N. albus IMSNU 20105 ${ }^{\mathrm{T}}$; 3, N. aquaticus IMSNU $13113^{\mathrm{T}}$; 4, N. aquiterrae KCCM 41647 ${ }^{\mathrm{T}}$; 5, N. ganghwensis IMSNU $14028^{\mathrm{T}}$; 6, N. jensenii IMSNU $22036^{\mathrm{T}}$; 7, N. luteus IMSNU $22020^{\mathrm{T}} ; 8$, N. nitrophenolicus KCTC 0457BP ${ }^{\mathrm{T}}$; 9, N. plantarum IMSNU $22067^{\mathrm{T}}$; 10, N. pyridinolyticus KCTC 0074BP ${ }^{\mathrm{T}}$; 11, N. simplex IMSNU $21329^{\mathrm{T}}$. +, Positive reaction; -, negative reaction; W, weakly positive; V, variable. All Nocardioides strains are positive for Gram reaction, catalase, gelatin hydrolysis, esterase lipase (C8) and leucine arylamidase; negative for acid-fastness, arginine dihydrolase, acid production from glucose (API 20NE kit), indole production from tryptophan, decomposition of adenine, alginate and cellulose, $\beta$-glucuronidase, $N$-acetyl- $\beta$-glucosaminidase and $\alpha$-fucosidase. Acetate was utilized by all strains; D-sorbitol, inulin, 2-propanol, L-ascorbate, polyethylene glycol, salicylate and thiamin were not. Data from Yi \& Chun (2004) except for Nocardioides aestuarii strain $\mathrm{JC}^{2} 056^{\mathrm{T}}$.

\begin{tabular}{|c|c|c|c|c|c|c|c|c|c|c|c|}
\hline Characteristic & 1 & 2 & 3 & 4 & 5 & 6 & 7 & 8 & 9 & 10 & 11 \\
\hline Mycelium and spore formation ${ }^{*}$ & - & + & - & - & - & - & + & - & - & - & - \\
\hline$\beta$-Galactosidase & + & + & - & + & + & - & + & - & - & + & + \\
\hline Nitrate reduction & - & - & + & + & + & + & - & - & - & + & - \\
\hline Casein & + & + & $\mathrm{W}$ & + & + & + & + & + & - & + & + \\
\hline DNA & + & $\mathrm{W}$ & + & + & + & + & + & + & - & + & + \\
\hline Aesculin & $\mathrm{W}$ & $\mathrm{W}$ & - & + & $\mathrm{W}$ & - & + & $\mathrm{w}$ & $\mathrm{W}$ & + & + \\
\hline Hypoxanthine & - & + & - & - & - & + & + & - & - & - & - \\
\hline Starch & - & + & - & + & + & - & + & - & - & + & $\mathrm{W}$ \\
\hline Alkaline phosphatase & $\mathrm{W}$ & + & $\mathrm{V}$ & - & + & $\mathrm{W}$ & $\mathrm{V}$ & + & - & + & + \\
\hline Esterase (C4) & + & + & $\mathrm{W}$ & - & $\mathrm{V}$ & $\mathrm{W}$ & + & - & + & - & - \\
\hline Lipase (C14) & - & - & - & - & - & - & - & - & $\mathrm{W}$ & - & - \\
\hline Valine arylamidase & + & - & $\mathrm{W}$ & - & + & $\mathrm{V}$ & - & + & $\mathrm{W}$ & $\mathrm{W}$ & $\mathrm{W}$ \\
\hline Cystine arylamidase & - & - & $\mathrm{V}$ & $\mathrm{W}$ & $\mathrm{W}$ & - & - & $\mathrm{W}$ & + & - & $\mathrm{W}$ \\
\hline Trypsin & + & + & $\mathrm{W}$ & + & - & $\mathrm{W}$ & + & + & - & + & + \\
\hline$\alpha$-Chymotrypsin & + & - & - & - & - & - & - & - & - & - & - \\
\hline Acid phosphatase & $\mathrm{W}$ & - & + & + & $\mathrm{W}$ & $\mathrm{V}$ & - & + & $\mathrm{W}$ & + & $\mathrm{W}$ \\
\hline Naphthol-AS-BI-phosphohydrolase & $\mathrm{W}$ & $\mathrm{W}$ & - & + & - & $\mathrm{V}$ & $\mathrm{V}$ & + & + & + & - \\
\hline$\alpha$-Galactosidase & - & - & - & - & + & - & - & - & - & - & - \\
\hline$\beta$-Galactosidase & + & $\mathrm{V}$ & - & - & + & - & $\mathrm{V}$ & - & - & - & - \\
\hline D-Cellobiose & + & + & - & + & + & - & + & - & + & + & - \\
\hline D-Fructose & + & + & + & + & + & - & - & + & + & + & - \\
\hline D-Galactose & + & + & + & + & + & - & - & - & - & + & - \\
\hline D-Glucose & + & + & + & + & + & + & + & + & - & + & + \\
\hline D-Mannitol & + & + & + & + & + & - & + & - & - & - & - \\
\hline D-Mannose & - & + & - & - & + & - & + & - & - & - & - \\
\hline D-Raffinose & $\mathrm{W}$ & - & - & - & + & - & - & - & - & - & - \\
\hline D-Ribose & - & - & - & - & - & - & - & + & - & + & - \\
\hline D-Salicin & - & $\mathrm{W}$ & - & - & + & - & - & - & + & - & - \\
\hline D-Xylose & + & + & + & + & + & - & + & + & + & + & - \\
\hline Glycerol & $\mathrm{W}$ & $\mathrm{W}$ & + & - & + & $\mathrm{W}$ & - & - & + & - & - \\
\hline
\end{tabular}


Table 1. cont

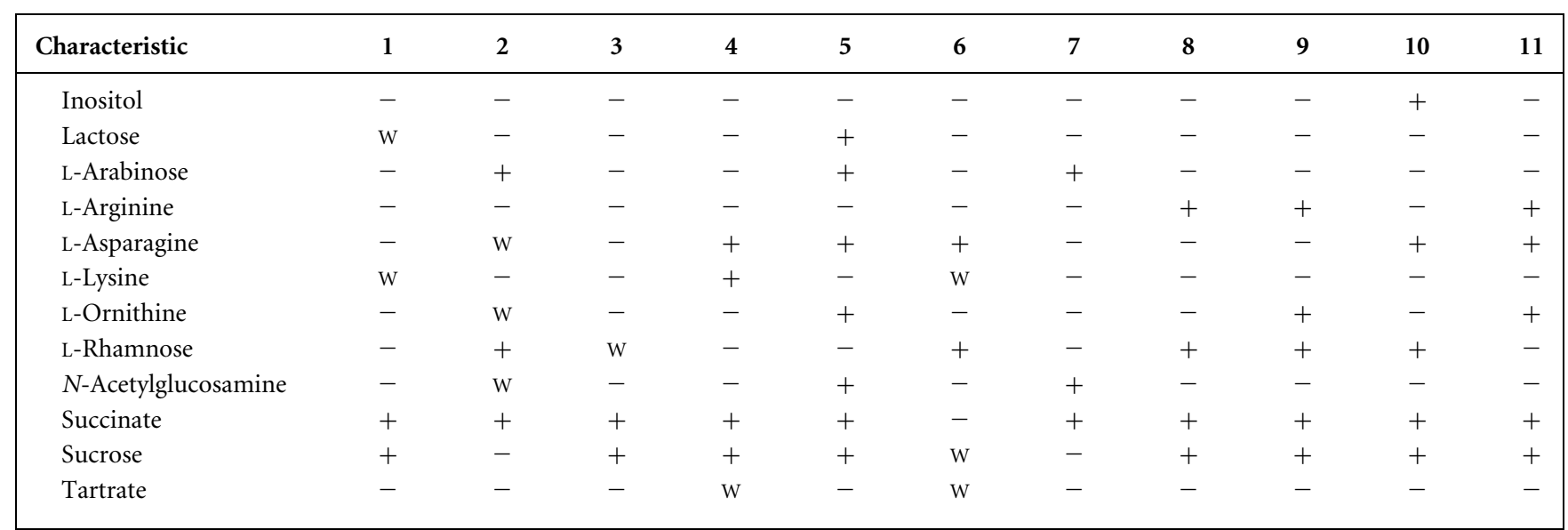

${ }^{\star}$ On agar media tested in this study.

\section{References}

Chun, J. \& Goodfellow, M. (1995). A phylogenetic analysis of the genus Nocardia with 16S rRNA gene sequences. Int J Syst Bacteriol 45, 240-245.

Collins, M. D., Cockcroft, S. \& Wallbanks, S. (1994). Phylogenetic analysis of a new LL-diaminopimelic acid-containing coryneform bacterium from herbage, Nocardioides plantarum sp. nov. Int J Syst Bacteriol 44, 523-526.

Lawson, P. A., Collins, M. D., Schumann, P., Tindall, B. J., Hirsch, P. \& Labrenz, M. (2000). New LL-diaminopimelic acid-containing actinomycetes from hypersaline, heliothermal and meromictic Antarctic Ekho Lake: Nocardioides aquaticus sp. nov. and Friedmanniella [correction of Friedmannielly] lacustris sp. nov. Syst Appl Microbiol 23, 219-229.

O’Donnell, A. G., Goodfellow, M. \& Minnikin, D. E. (1982). Lipids in the classification of Nocardioides: reclassification of Arthrobacter simplex (Jensen) Lochhead in the genus Nocardioides (Prauser) emend. O'Donnell et al. as Nocardioides simplex comb. nov. Arch Microbiol 133, 323-329.

Prauser, H. (1976). Nocardioides, a new genus of the order Actinomycetales. Int J Syst Bacteriol 26, 58-65.

Prauser, H. (1986). Genus Nocardioides Prauser 1976, 61 ${ }^{A L}$. In Bergey's Manual of Systematic Bacteriology, vol. 2, pp. 1481-1485. Edited by P. H. A. Sneath, N. S. Nair, M. E. Sharpe \& J. G. Holt. Baltimore: Williams \& Wilkins.
Stackebrandt, E. \& Goebel, B. M. (1994). Taxonomic note: a place for DNA-DNA reassociation and 16S rRNA sequence analysis in the present species definition in bacteriology. Int J Syst Bacteriol 44, 846-849.

Staneck, J. L. \& Roberts, G. D. (1974). Simplified approach to the identification of aerobic actinomycetes by thin-layer chromatography. Appl Microbiol 28, 226-231.

Suzuki, K.-I. \& Komagata, K. (1983). Pimelobacter gen. nov., a new genus of coryneform bacteria with LL-diaminopimelic acid in the cell wall. J Gen Appl Microbiol 29, 59-71.

Swofford, D. L. (1998). Phylogenetic analysis using parsimony (PAUP). Version 4. Sunderland, MA: Sinauer Associates.

Yi, H. \& Chun, J. (2004). Nocardioides ganghwensis sp. nov., isolated from tidal flat sediment. Int J Syst Evol Microbiol 54, 1295-1299.

Yoon, J.-H., Rhee, S.-K., Lee, J.-S., Park, Y.-H. \& Lee, S. T. (1997). Nocardioides pyridinolyticus sp. nov., a pyridine-degrading bacterium isolated from the oxic zone of an oil shale column. Int J Syst Bacteriol 47, 933-938.

Yoon, J.-H., Cho, Y.-G., Lee, S. T., Suzuki, K., Nakase, T. \& Park, Y.-H. (1999). Nocardioides nitrophenolicus sp. nov., a p-nitrophenoldegrading bacterium. Int J Syst Bacteriol 49, 675-680.

Yoon, J.-H., Kim, I.-G., Kang, K. H., Oh, T.-K. \& Park, Y.-H. (2003). Nocardioides aquiterrae sp. nov., isolated from groundwater in Korea. Int J Syst Evol Microbiol 54, 71-75. 